\title{
A Proposed Solution to the Puzzle of Antisuit Injunctions
}

\author{
John Ray Phillips, III $\dagger$
}

The question of whether and how a court of one jurisdiction should give effect to an equitable decree of a court in another jurisdiction arises continually in the legal world and presents itself in many different forms. Leading scholars of the early to mid-twentieth century debated the question in the context of the effect to be given to foreign land decrees. ${ }^{1}$ More recently, the Supreme Court considered the question with regard to a state injunction barring a litigant from testifying against General Motors anywhere in the United States. ${ }^{2}$ This Comment examines what effect should be given to "antisuit" injunctions, injunctions that forbid litigants from proceeding in identical or related legal proceedings in sister states.

The law of antisuit injunctions is simple, if somewhat conflicted. A court in State A may constitutionally enjoin litigants from instituting or proceeding with an identical or similar legal action in another state. Whether a court will grant such an injunction depends on the movant's ability to satisfy a series of conditions. These conditions include the interest of the forum state in hearing the cause of action, the interest of the state that will be affected by the injunction, and, in some states, the burden that parallel litigation would place on the litigants.

The greatest variation among courts is found in their willingness to consider the burden placed on litigants. This burden arises in the consideration of whether to grant an antisuit injunction to avoid duplicative litigation. In states that recognize this circumstance as a legitimate justification for issuance, antisuit injunctions are much easier

$\dagger$ B.A. Duke University 1999; J.D. Candidate 2003, The University of Chicago.

1 See, for example, Brainerd Currie, Full Faith and Credit to Foreign Land Decrees, $21 \mathrm{U}$ Chi L Rev 620,678 (1954) (arguing that foreign jurisdictions should abide by an equitable decree to convey land in another jurisdiction); Herbert F. Goodrich, Note, The Enforcement of a Foreign Equitable Decree, 5 Iowa L Bull 230, 232 (1920) (arguing in favor of the recognition of foreign land decrees); Willard Barbour, The Extra-Territorial Effect of the Equitable Decree, 17 Mich L Rev 527, 532 (1919) (arguing that a foreign land decree ought to be afforded full faith and credit under the Constitution). See also Fall v Eastin, 215 US 1, 14 (1909) (denying full faith and credit to a foreign land decree).

2 See Baker v General Motors, Corp, 522 US 222, 231-34 (1998) (holding that Missouri need not give full faith and credit to an injunction issued by Michigan barring a party from testifying in trials relating to that party's expert knowledge of the defendant's production practices). 
to obtain. Accordingly, these states are said to employ a "lax" standard; states that do not do so are said to have a "strict" standard.

Antisuit injunctions present difficult issues for courts in sister states. When a court in State A issues an antisuit injunction, a court in State B presiding over a similar cause of action involving the same parties has three possible courses of action: (1) it may recognize the injunction and stay the litigation before it, pending the resolution of the cause of action in State A; (2) it may ignore the injunction and allow the litigation to proceed concurrently with the litigation in State A; or (3) it may ignore the injunction, allow the litigation to proceed concurrently, and issue an antisuit injunction of its own, forbidding litigants from participating in proceedings in State A. None of these options is particularly appealing.

A decision to stay the litigation gives the issuing court in State A exclusive jurisdiction over the cause of action. It denies to litigants the benefit of having the case heard in State B simply because the court in State $A$ issued an antisuit injunction first-providing a perverse incentive for courts to be proactive in issuing antisuit injunctions. If the State B court ignores the antisuit injunction and proceeds with the suit before it, the parties will find themselves in a Catch-22, forced to choose between two bad options: a finding of contempt in State A for proceeding in violation of its antisuit injunction, and a default judgment in State B for not participating in litigation. ${ }^{4}$ Finally, if the State $B$ court issues its own antisuit injunction, the litigants may be left without legal recourse, enjoined from proceeding with the cause of action in both states.

This Comment seeks to underline the difficulties posed by the issuance of antisuit injunctions, and to suggest a framework within which courts may evaluate antisuit injunctions when called on to respond to them. The Comment first answers basic legal questions about antisuit injunctions. Part I.A explains what an antisuit injunction is and how it might affect the litigation process. Part I.B describes the standards under which an antisuit injunction may be granted and explains the variation among states. Part I.C discusses how courts outside the issuing state treat antisuit injunctions and the effect such injunctions have on litigants. Part II of this Comment addresses the po-

3 See, for example, James v Grand Trunk Western Railroad Co, 14 Ill 2d 356, 152 NE2d 858, 867 (1958) (upholding an Illinois court's refusal to recognize a Michigan antisuit injunction); Owens-Illinois, Inc $v$ Webb, 809 SW2d 899, 900 (Tex App 1991) (listing grounds for antisuit injunction in a case involving an appeal of a Texas Court's injunction of a Canadian suit).

4 Compare Nowell v Nowell, 157 Conn 470, 254 A2d 889, 896 (1969) (noting that defendant had been held in contempt for proceeding in a Texas court in violation of a Connecticut antisuit injunction), with Nowell v Nowell, 408 SW2d 550, 555 (Tex App 1966) (refusing to stay litigation due to the issuance of an antisuit injunction by Connecticut). 
tential relevance of the Full Faith and Credit Clause to the recognition and issuance of antisuit injunctions. The Supreme Court has not extended the Clause to affect either, and, for pragmatic reasons, is highly unlikely to do so in the future.

The remainder of this Comment discusses the problems posed by antisuit injunctions and suggests possible solutions. Part III evaluates the standards for issuing antisuit injunctions. It argues that, while antisuit injunctions are valuable in some circumstances, the lax standard for issuance should be abandoned for three reasons: (1) it invariably leads to conflict between the courts that issue the injunctions and the courts that are affected by them; (2) it does not present a compelling rationale for extraterritorial recognition; and (3) it is in discord with traditional notions of parallel litigation. Based on Part III's argument against a lax standard for issuing antisuit injunctions, Part IV.A urges courts to (1) differentiate between injunctions issued based on lax standards and those based on strict standards; and (2) only recognize injunctions granted under the strict standard.

Part IV.B considers competing frameworks within which a court may evaluate and respond to an antisuit injunction issued by a court in a sister state. In considering these frameworks, the remainder of the Comment asks how much deference a court may give to such an injunction without surrendering control over the cause of action. These dual considerations find their roots in the concepts of reciprocity and comity between courts.

\section{THE LAW OF ANTISUIT INJUNCTIONS}

A. What is an Antisuit Injunction?

An antisuit injunction is a legal order barring litigants from instituting or prosecuting the same or a similar action in another state. ${ }^{6} \mathrm{~A}$ court may employ all of its contempt power to force the litigants before it to comply with such an injunction. These contempt powers include litigation penalties and reprimands, and monetary fines. Never-

5 US Const Art IV, $\$ 1$.

6 See E.H. Schopler, Annotation, Extraterritorial Recognition of, and Propriety of Counterinjunction Against, Injunction Against Actions in Courts of Other States, 74 ALR 2d $829 \$ 1$ (describing an antisuit injunction as "the power of a court of equity, where it has jurisdiction of the cause and of the parties, to enjoin a person from beginning or prosecuting an action in another state").

7 See, for example, Mulligan v Piczon, $566 \mathrm{~Pa} 214,779$ A2d 1143, 1149 (2001) (asserting that "[i]t is fundamental that courts possess inherent power to enforce compliance, and to punish non-compliance, with their lawful orders," but that "the precise contours of the judicial contempt power are sometimes difficult to discern"); Hart v McChristian, 344 Ark 656, 42 SW3d 552, 562 (2001) ("A court's contempt power may be wielded ... to punish disobedience of the court's orders."). For an example of contempt penalties in the context of antisuit injunctions, see Roggenkamp v Roggenkamp, 25 Md App 243, 333 A2d 374, 378 (1975) (holding that a litigant proceeding 
theless, they are not limitless: Contempt penalties are not entitled to full faith and credit, and must be enforced within the state in which they are issued. ${ }^{8}$ A litigant may proceed in the face of an antisuit injunction issued by State $A$ without fear that the contempt penalties that she may face in State A will affect litigation in State B. Accordingly, a court in State B must decide for itself the effect to be given to State A's antisuit injunction.

Antisuit injunctions can be a powerful tool in complex litigation. The issuance of an antisuit injunction greatly increases the probability that the issuing court will be the only court to hear a cause of action and dramatically decreases the chance that another court will preempt the jurisdiction of the issuing court by reaching a final judgment first." It also avoids the possibility that two virtually identical causes of action will proceed concurrently in parallel courts. From the perspective of the litigants, the issuance of an antisuit injunction may heavily influence the outcome of the cause of action: To the extent that the injunction determines the forum for litigation, it decides the choice-oflaw rules, and often the substantive law that will govern the case."

in spite of an antisuit injunction "may well be in violation of the California injunction and subject to contempt penalties there," but that the "jurisdiction of our courts to accommodate his divorce action is unhampered by the outstanding injunction"); Nowell v Nowell, 157 Conn 470, 254 A2d 889, 896 (1969) (stating that the appropriate punishment for civil contempt comes in the form of monetary penalties to be administered in the final judgment).

8 See Polly J. Price, Full Faith and Credit and the Equity Conflict, 84 Va L Rev 747, 790-91 (1998) ("If conduct outside of a jurisdiction is appropriately the subject of a state court injunction and a party is aggrieved by violation of an extraterritorial injunction, absent full faith and credit accorded the injunction elsewhere, the party is left to initiate contempt proceedings in the original court for violation of the injunction.").

9 For an example of strategic use of an antisuit injunction in complex litigation, see Forum Insurance Co v Bristol-Myers Squibb Co, 929 SW2d 114, 115 (Tex App 1996) (recounting the facts of a suit brought by an insured manufacturer of breast implants against its liability insurers where an antisuit injunction was sought to enjoin all parties in New York proceedings).

10 See Nowell, 254 A2d at 894 ("Connecticut must recognize the Texas judgment under the mandate of full faith and credit despite the fact that it was obtained in defiance of a Connecticut antisuit injunction."). In instances of concurrent litigation in state courts, litigants "race to res judicata." The first litigant to get a judgment in his favor is then able to short circuit litigation in the alternative forum by entering the judgment in the sister jurisdiction. Under principles of res judicata and the Full Faith and Credit Clause, the courts in every state are bound to follow the final judgment reached in every other jurisdiction. See Fauntleroy v Lum, 210 US 230 (1908) (holding that the Full Faith and Credit Clause requires each state to abide by all final judgments issued in sister states).

11 See, for example, Alabama Great Southern Railroad Co v Carroll, 97 Ala 126, 11 S 803, 807-08 (1892) (looking to Alabama choice of law rules in deciding whether to apply Mississippi or Alabama tort law).

12 The choice of law rule that a state applies will often determine the substantive law that applies to a multi-state cause of action. See, for example, Paul $v$ National Life, $177 \mathrm{~W}$ Va 427,352 SE2d 550, 551 (1986) (deciding whether to employ a traditional choice of law rule or the Second Restatement in order to reach the question of whether the law of Indiana or Virginia shall apply). 


\section{B. The Issuance of Antisuit Injunctions in State Courts}

The grounds on which courts may issue antisuit injunctions vary among states. In virtually every state, a motion for an antisuit injunction must meet the standards that apply to any request for a preliminary injunction: a demonstrated potential for serious and irreparable harm and a likelihood of prevailing on the merits. ${ }^{13}$ All state courts find that courts should take greater care in issuing antisuit injunctions than they apply in issuing other injunctions, ${ }^{14}$ though they disagree on how much extra care.

State courts have taken two distinct approaches in answering this question. ${ }^{15}$ The more stringent approach issues antisuit injunctions in three situations: (1) when there has been a finding that the jurisdiction of the issuing court is being challenged; ${ }^{16}(2)$ when it is necessary to protect an important public policy of the forum; ${ }^{17}$ and (3) when a lawsuit has been filed in bad faith in an alternative forum. The second approach is more lax. It allows for the issuance of an antisuit injunction when any one of the conditions listed above is met. Additionally, it al-

13 Somewhat surprisingly, some courts require a lesser showing than would be required for the issuance of a regular preliminary injunction. Compare Golden Rule Insurance Co v Harper, 925 SW2d 649,651 (Tex 1996) (declining to require the consideration of the likelihood of success on the merits in determining whether to grant antisuit injunctions); Admiral Insurance Co $v$ Atchison, Topeka and Santa Fe Railway Co, 848 SW2d 251, 257-58 (Tex App 1993) (overruled on different grounds), with Total Minatome Corp v Santa Fe Minerals, Inc, 851 SW2d 336, 339 (Tex App 1993) (requiring that the movant demonstrate a likelihood of success on the merits).

14 Virtually every court, no matter what its willingness to grant antisuit injunctions is in practice, refers to the issuance of antisuit injunctions as a rare remedy. See, for example, Auerbach v Frank, 685 A2d 404, 409 (DC 1996) (noting that antisuit injunctions "bear[ a very heavy burden of justification"); Total Minatome, 851 SW2d at 339 (holding that antisuit injunctions should be issued "sparingly and only in special circumstances"); Roberts Realty of the Bahamas, Ltd $v$ Miller and Solomon (Bahamas), Ltd, 234 S2d 417, 418 (Fla Dist Ct App 1970) (reversing lower court's antisuit injunction because there was no showing that the injunction was "absolutely necessary").

15 Federal courts are similarly split on the grounds on which an antisuit injunction should be granted. The District of Columbia, Second, and Sixth Circuits have applied an extremely high bar to the granting of antisuit injunctions. In contrast, the Fifth, Seventh, and Ninth Circuits have adopted a more relaxed approach to the question. See Gary Born, International Civil Litigation in United States Courts 477 (Kluwer Law International 3d ed 1996) (explaining the split between circuits in granting antisuit injunctions). See also Haig Najarian, Note, Granting Comity Its Due: A Proposal to Revive the Comity-Based Approach to Transnational Antisuit Injunctions, $68 \mathrm{St}$ John's L Rev 961, 984 (1994) (arguing in favor of the stricter standard for antisuit injunctions for reasons of international comity).

16 See Auerbach, 685 A2d at 407 (examining the justifications for issuing an antisuit injunction). The first prong of this test is not a general grant to issue an injunction whenever concurrent litigation arises. Rather, the grant is limited to instances where litigation in the alternative forum would "divest the [ ] court of jurisdiction." Id.

17 As in choice-of-law cases, the extent of this exception depends on the meaning attached to it by the forum court. For a broad reading of the public policy rationale, see Monsanto Co $v$ Davis 25 SW3d 773, 788 (Tex App 2000) (granting an antisuit injunction to preserve "the important public policy" of retaining "efficiency of the class [certification] procedure" in class action lawsuits). 
lows for the issuance of an injunction in order to prevent duplicative litigation. ${ }^{18}$ The approaches followed by courts in the District of Columbia and Texas illustrate how the two standards for issuance are applied.

1. The strict standard.

In Auerbach v Frank, ${ }^{19}$ the Court of Appeals for the District of Columbia, D.C.'s highest court, considered the question of whether a "mirror-image" proceeding in a court of another state was sufficient justification for the issuance of an antisuit injunction. ${ }^{20}$ The D.C. court found that it was not, basing its decision on "[p]roper respect for the courts of the other sovereign state, ${ }^{, 21}$ and a concern that the foreign court affected by its injunction would retaliate by issuing an injunction of its own. These concerns were sufficiently grave for the court to hold that antisuit injunctions are only appropriate to avoid "an irreparable miscarriage of justice.".23 They were not appropriate to address "concerns such as duplication of parties and issues, the expense and effort of simultaneous litigation in two courts, and the danger of a race to judgment and inconsistent adjudications. ${ }^{34}$ Rather, an antisuit injunction should be awarded in only three instances: "(1) to protect the forum's jurisdiction ... (2) to prevent evasion of the forum's important public policies,", or (3) where "the [foreign] suit was brought in bad faith or to 'vex[] or harass[] the party seeking the injunction.","

Each of the court's justifications depends upon the interests of the forum rather than those of the parties. The first justification is lim-

18 See Brown v Brown, 120 RI 340,387 A2d 1051, 1055 (1978) (affirming the issuance of an antisuit injunction because the injunction was "warranted in order to prevent a multiplicity of suits"); Medtronic, Inc v Advanced Bionics Corp, 630 NW2d 438, 450-51 (Minn Ct App 2001) (affirming a lower court's issuance of an antisuit injunction solely through the application of a five prong test used in deciding whether to grant preliminary injunctions and reviewing the lower court's decision under a "clear abuse of discretion" standard).

19685 A2d 404 (DC 1996) (involving a parallel suit between two law firms, one brought in $\mathrm{DC}$, the other in Maryland).

20 Id at 406.

21 Id at 409. The D.C. court references Peck v Jenness, 48 US (1 How) 612 (1849), to articulate its concern that, "if one court may enjoin, the other may retort by injunction, and thus the parties be without remedy." Auerbach, 685 A2d at 409 .

22 See Auerbach, 685 A2d at 409.

23 Id at 407.

24 Id at 409. See also Roman v Sunshine Ranchettes, Inc, 98 AD2d 744, 469 NYS2d 449, 451 (NY App Div 1983) ("The mere fact that an action was first commenced in this State is insufficient to justify enjoining a party from litigating in another State."); Roberts Realty of the Bahamas, Ltd v Miller and Solomon (Bahamas), Ltd, 234 S2d 417, 418 (Fla Dist Ct App 1970) (reversing an antisuit injunction issued by a lower court because the injunction was not "absolutely necessary to protect any interest of this state").

25 Auerbach, 685 A2d at 407.

26 Id at 409. 
ited to those instances where another forum has acted to "divest the court of jurisdiction,", presumably by issuing an antisuit injunction of its own. The second justification - to prevent evasion of the forum's public policies-is, by its terms, related to the interests of the forum. The third justification, while extending protection to one of the parties, represents the forum's policy of preventing abuse of the court system and punishing bad actors. The import of this distinction between the interests of the parties and the interests of the forum becomes clear in the discussion of the lax standard below.

\section{The lax standard.}

Like the Court of Appeals of the District of Columbia, the Texas Supreme Court declared that antisuit injunctions should be used "sparingly, and only in very special circumstances." considerably more expansive than the D.C. court's. It allows courts to issue antisuit injunctions in order "to prevent a multiplicity of suits" bach." Allowing antisuit injunctions under this additional circumstance greatly enhances the availability of antisuit injunctions as a litigation tool, and embodies a different approach to parallel litigation.

The lax standard may be expanded to include almost any case of complex litigation. The development of case law in Texas provides a good example. Following the adoption of a lax standard in Golden Rule Insurance Co v Harper, ${ }^{31}$ several Texas appellate courts have held that a movant need not show that there are actually multiple lawsuits in order to obtain an antisuit injunction; rather, he need only demonstrate the possibility of lawsuits in another forum. ${ }^{32}$ Such a possibility exists in virtually any case of complex, multi-state litigation. ${ }^{33}$ Furthermore, the rule that a court may issue antisuit injunctions under a certain standard quickly gives way to a more expansive rule that a

27 Id at 407.

28 Golden Rule Insurance Co v Harper, 925 SW2d 649, 651 (Tex 1996), quoting Christensen $v$ Integrity Insurance Company, 719 SW2d 161, 163 (Tex 1986).

29 Id at 651.

30 See $685 \mathrm{~A} 2 \mathrm{~d}$ at 409 (concluding that the injunction issued by the D.C. court was not warranted).

31905 SW2d 804 (1996).

32 See Bridas Corp v Unocal Corp, 16 SW3d 887, 891 (Tex App 2000) (finding that an antisuit injunction is appropriate where one party may bring, but has not brought, a parallel lawsuit); Forum Insurance Co v Bristol-Myers Squibb Co, 929 SW2d 114, 120 (Tex App 1996) (holding that "clear equity favors all parties seeking a completion and finality to their dispute in a single proceeding without the vexation of potentially multiplicitous and harassing litigation").

33 See James P. George, Parallel Litigation, 51 Baylor L Rev 769, 969-86 (1999) (examining the multi-state nature of complex litigation). 
court should do so whenever the requirements for the injunction are met. $^{34}$

3. Conceptions of parallel litigation under the strict and lax standards.

Not only do the strict and lax standards result in a different incidence of antisuit injunctions, but they also embody conflicting conceptions of how parallel litigation should proceed. The prevailing conception of parallel litigation is that courts should allow litigation to proceed concurrently until one court reaches a final judgment. ${ }^{35}$ Generally, this rule has been justified on the ground that coordinate sovereigns should respect one another's legitimate assertion of jurisdiction. ${ }^{36}$ The strict standard for granting antisuit injunctions accords with this belief: The fewer antisuit injunctions that a court issues, the more likely it is that litigation will proceed naturally in both forums. A second conception of parallel litigation emphasizes that it is wasteful and duplicative. Under this view, courts should avoid it whenever possible. This conception coincides with a liberal use of antisuit injunctions. By preempting parallel litigation early in the process, both the litigants and the courts save time and resources.

The two standards for issuing antisuit injunctions also embody different conceptions of the role of antisuit injunctions themselves. As noted, the strict standard envisions the antisuit injunction as a tool of the court, to be used when the forum's interests are chalienged. In comparison, the lax standard understands the injunction as a tool of litigants, a weapon in the rough-and-tumble world of complex litigation.

The practical importance of this difference in standards can be seen in an evaluation of its effect on parallel litigation. Antisuit injunc-

34 Forum Insurance, 929 SW2d at 117 (finding that a court "should protect its jurisdiction by enjoining the filing or prosecution of subsequent lawsuits involving the same controversy") (emphasis added). See also Brown v Brown, 120 RI 340, 387 A2d 1051, 1055 (1978) (finding that "the injunction was warranted in order to prevent a multiplicity of suits"); Stambaugh v Stambaugh, $458 \mathrm{~Pa} \mathrm{147,} 329$ A2d 483, 491 (1974) (Roberts dissenting) ("The logical, realistic, and reasonable rule is that once personal jurisdiction over a party is obtained, an anti-suit injunction, if warranted, may validly issue.").

35 This is the predominant rule when dealing with parallel litigation in the courts of independent sovereigns. See Colorado River Water Conservation District v United States, 424 US 800 , 817-18 (1976) (holding that federal courts should entertain suits concurrently pending at the state level); Laker Airways Ltd v Sabena, Belgian World Airlines, 731 F2d 909, 926 (DC Cir 1984) (finding that, between nations, the traditional model is to allow parallel litigation to proceed concurrently); St. Paul Surplus Lines Insurance Co v Mentor Corp, 503 NW2d 511, 515 (Minn Ct App 1993) (holding that the same cause of action may proceed in two different states concurrently).

36 For an informative discussion of the connection of this norm to a strict standard of issuance of antisuit injunctions, see Laker Airways, 731 F2d at 926-33. 
tions will play a limited role in a jurisdiction that employs the strict standard. They are relegated to use in situations in which a party is a bad actor, there is an important public policy issue at stake, or the alternative forum is actively attempting to deprive the issuing court of jurisdiction. In contrast, the application of the lax standard-which, as stated above, considers the avoidance of a possibility of a multiplicity of suits a worthy justification-elevates antisuit injunctions to the level of a potential litigation tool in virtually every instance of parallel litigation.

The importance of these theoretical and practical differences will only increase as the prevalence of parallel litigation increases. Already there has been "an expansion both in the incidence and the subject matter of parallel lawsuits." ${ }^{37}$ This expansion is likely to continue, especially in light of an increasingly well-funded plaintiff's bar $^{38}$ and decreasing practical, financial, and technological burdens to travel and the filing of legal documents.

\section{State Courts and the Recognition of Antisuit Injunctions}

The extraterritorial effect of antisuit injunctions is limited. Courts in other states do not feel compelled to honor these injunctions ${ }^{40}$ and have not been required to do so by the Full Faith and Credit Clause." Traditionally, interstate recognition of antisuit injunctions is said to be a matter of "comity," defined as "the nonmandatory acceptance by one jurisdiction of the law of another." ${ }^{.33}$ In practice, comity has never been a weighty, let alone dispositive, consideration for courts. As Jus-

37 George, 51 Baylor L Rev at 773 (cited in note 33).

38 See Michael M. Bowden, A Line of Credit for Litigation Expenses, 2001 Law Weekly USA B13 (Aug 20,2001) (reporting that over the past decade at least ten states have made it easier for attorneys to borrow money to help fund litigation and finding that companies have arisen that specialize in providing funds for this purpose).

39 See Robert Plotkin, Electronic Court Filing: Past, Present, and Future, 44 Boston Bar J 4, 15-16 (May/June 2000) (writing that many states are developing or have developed electronic filing systems and that these systems have the potential to greatly ease the burden of filing). See also Javad Mostofizadeh, Reducing the Costs of Civil Litigation: Using New Technologies, Public Law Research Institute (1995), available online at <http://www.uchastings.edu/plri/fal95tex/ newtech.html> (visited Apr 8,2002) (describing myriad ways in which technology will reduce the cost of civil litigation).

40 See, for example, Robbins v Reliance Insurance Co, 2001 Tex App LEXIS 7367, $* 13$ (explaining that it would be "contrary to Texas law and public policy for a Texas state court to stay a pending case pursuant to an anti-suit injunction ... issued by [another] state court").

41 See Baker v General Motors Corp, 522 US 222, 236 n 9 (1998) (noting that the Court has held it impermissible for a state court to enjoin a suit from proceeding in federal court). For further discussion of constitutional issues, see Part II.

42 See Cunningham v Cunningham, 25 Conn Supp 221, 200 A2d 734, 736 (Super Ct 1964) (holding that a court may "in its discretion recognize [an antisuit injunction] as a matter of comity").

43 Lea Brilmayer and Jack L. Goldsmith, Conflict of Laws, Cases and Materials xxix (Aspen 5 th ed 2002). 
tice Story wrote, it as an "imperfect obligation, like that of beneficence, humanity, and charity." Not surprisingly, then, when considering whether to recognize antisuit injunctions, courts pay homage to comity but seldom invoke it as the sole ground for their decision.

In fact, the existence of an antisuit injunction plays a minimal role in a court's decision to stay a cause of action or allow it to proceed. Courts generally ignore the injunction unless they independently reach a determination that the litigation would be better pursued outside their borders. ${ }^{46}$ For instance, they decline to recognize antisuit injunctions when an injunction has been issued in violation of the firstto-file rule; ${ }^{47}$ when an injunction would not have been issued under the law in their state $;^{45}$ or when recognition of an injunction would allow a plaintiff to avoid the law of their state. There is little cost to a court that chooses to ignore another court's antisuit injunction: So long as it arrives at final judgment first, its judgment is entitled to full faith and credit, even when reached by a party in violation of an antisuit injunction of another state, and even when the party seeks recognition of the final judgment in the issuing state."

Nevertheless, the practice of ignoring an antisuit injunction places a court in the strange position of siding with litigants against the order of a court in a sister state. As one judge remarked, this situation makes the court a sort of "aider and abettor in the violation of the injunction

44 Joseph Story, Commentaries on the Conflict of Laws 43 (Little, Brown 3d ed 1846).

45 That comity seldom drives the decision to recognize antisuit injunctions has been openly acknowledged by at least one court. See Abney $v$ Abney, 176 Ind App 22, 374 NE2d 264, 268 (1978) (recognizing that the controlling factor was not the issuance of an antisuit injunction but whether the state issuing the injunction was the first to obtain jurisdiction of cause).

46 See id (holding that the court does not need to follow the antisuit injunction of another state).

47 The first-to-file rule states that "where two courts have concurrent jurisdiction, the first to acquire jurisdiction generally has priority to decide the case." Medtronic, Inc v Advanced Bionics Corp, 630 NW2d 438, 448-50 (Minn App 2001) (deciding against the application of the first-to-file rule because the defendant "filed suit in California specifically to avoid Minnesota law"). Antisuit injunctions issued in violation of the first-to-file rule are perhaps the most likely to be ignored. See James v Grand Trunk Western Railroad Co, 14 Ill2d 356, 152 NE2d 858, 867 (1958) (refusing to recognize a Michigan antisuit injunction where it was issued in violation of the first-to-file rule); Nichols \& Shepard Co v Wheeler, $150 \mathrm{Ky} \mathrm{169,150} \mathrm{SW} \mathrm{33,} 34$ (1912) (finding that an antisuit injunction against a party did not bar that party from proceeding in Kentucky where it did not appear that the Tennessee action was instituted before the Kentucky suit).

48 See Robbins, 2001 Tex App LEXIS 7367 at *13 (finding that a Texas court should not abide by a Pennsylvania court's antisuit injunction "unless the relevant Texas Insurance Code provisions relating to stays of pending suits against insurers placed under an order of rehabilitation have been complied with"). In essence, the Texas appeals court in Rabbins held that it will not enforce a foreign court's antisuit injunction unless the facts of the case would merit a stay in Texas court.

49 See, for example, Stambaugh v Stambaugh, 458 Pa 147, 329 A2d 483, 487 (1974) (giving full faith and credit to a Florida judgment issued in spite of a Connecticut antisuit injunction and explaining that, "the issuance of an anti-suit injunction ... cannot affect a state's obligation to give full faith and credit to an out-of-state divorce decree"). 
... in contempt of the court whose injunction it helps the plaintiff to violate." Litigants are also placed in a precarious position when a court does not recognize an antisuit injunction. They are forced to choose between participating in the litigation and facing the consequences from the issuing jurisdiction on the one hand, and declining to obey the injunction and risking an adverse default judgment on the other."

A final choice available to a court affected by another court's antisuit injunction is to issue an antisuit injunction of its own. Courts in every state recognize this as a legitimate reason to issue such an injunction, but that is not to say that it is invoked without caution. ${ }^{52} \mathrm{Re}-$ sorting to this measure creates a great deal of tension between the two courts with conflicting orders and puts the parties in an exceedingly difficult situation. Justice Breyer noted this predicament during oral argument in Baker v General Motors Corp, explaining that "you have one State telling them you have to do a thing and another State saying you can't do a thing .... and that produce[s] a terrible practical mess."

Conflicting antisuit injunctions may even lead to a situation in which the litigants are in effect barred from proceeding on the cause of action in any state. This was the result of recent mirror-image litigation in California and Minnesota. ${ }^{36}$ In response to an antisuit injunc-

50 Doyle v Northern Pacific Railway Co, 55 F2d 708, 710 (D Minn 1932) (expressing reservations about the Minnesota rule that foreign antisuit injunctions did not deserve recognition in Minnesota).

51 Justice Breyer recognized the unusual nature of this situation during oral argument in Baker $v$ General Motors, 522 US 222 (1998). Breyer remarked that if courts did not have to enforce the injunctions of other courts,

you run into the possibility that ... those under injunctions, will get under conflicting injunctions, and then they'll really be in a mess because in-you know, you have one State telling them you have to do a thing and another State saying you can't do a thing ... and that would produce a terrible practical mess, so between those two evils, it seems better to [enforce the injunction and require the restrained party to seek a modification in the issuing state].

Transcript of Oral Argument, Baker $v$ General Motors Corp, No 96-653, *6 (Oct 15, 1997) (available on Lexis at 1997 US Trans LEXIS 58). For a practical example of this difficulty, see note 4 (discussing the path of the Nowell litigation in Connecticut and Texas).

52 See Born, International Civil Litigation at 476 (cited in note 15).

53522 US 222 (1998).

54 Transcript of Oral Argument, Baker No 96-653 at $* 6$ (cited in note 51).

55 See, for example, Nowell $v$ Nowell, 408 SW2d 550, 555 (Tex App 1966) (allowing party to proceed in derogation of Connecticut antisuit injunction and issuing antisuit injunction of its own); Forum Insurance Co v Bristol-Myers Squibb Co, 929 SW2d 114, 119 (Tex App 1966) (noting that "nothing ... prohibits the New York trial court from issuing [an antisuit injunction in response to the injunction issued by a Texas court] thus preventing any party from obtaining a remedy").

56 For a complete summary of the litigation in both Minnesota and California courts, see Medtronic, Inc v Advanced Bionics Corp, 630 NW2d 438, 444-48 (Minn Ct App 2001) (discussing litigation in Minnesota courts); Advanced Bionics Corp v Medtronic, Inc, 105 Cal Rptr 2d 265, 265-77 (Ct App 2001) (discussing litigation in California courts). 
tion issued by a Minnesota court, a court in California responded in kind, so that each state barred the parties from proceeding in the courts of the other. Neither court relieved the parties from its injunction and both were affirmed under appellate review. The courts' dueling antisuit injunctions paralyzed both parties.

\section{ANTISUIT INJUNCTIONS AND THE FULL FAITH AND CREDIT CLAUSE OF THE U.S. CONSTITUTION}

The Full Faith and Credit Clause ${ }^{s 8}$ potentially bears on the legitimacy of both the issuance and recognition of antisuit injunctions. Thus far, however, the Supreme Court has held that it does not limit the power of state courts in either respect.

\section{A. Issuance}

In 1890, the Supreme Court was first asked to resolve the question of whether state courts could issue antisuit injunctions, given the restraints of the Full Faith and Credit Clause. ${ }^{59}$ The challenge arose when a New York bankruptcy court issued an injunction forbidding creditors from pursuing identical claims in Massachusetts. ${ }^{60}$ The creditors appealed the injunction, arguing that the New York court did not have the power to issue it. They claimed that the injunction unconstitutionally interfered with litigation in Massachusetts, in effect denying full faith and credit to those proceedings. ${ }^{61}$

In reaching its decision, the Court noted that several state courts had ignored antisuit injunctions issued in sister states. ${ }^{62}$ These state courts worried that allowing antisuit injunctions might lead to sys-

57 See Medtronic, 630 NW2d at 448 (holding that the Minnesota injunction was valid); $A d$ vanced Bionics, 105 Cal Rptr 2d at 277 (holding that the California injunction was valid), cert granted 25 P3d 1078 (2001).

58 US Const Art IV $\S 1$, which reads "Full Faith and Credit shall be given in each State to the public Acts, Records, and judicial Proceedings of every other State. And the Congress may by general Laws prescribe the Manner in which such Acts, Records, and Proceedings shall be proved, and the Effect thereof."

59 See Cole v Cunningham, 133 US 107, 134 (1890) (holding that the Full Faith and Credit Clause did not bar the issuance of antisuit injunctions).

60 Id at 112-13.

61 See id at 111. A constitutional challenge was also raised on the ground that antisuit injunctions violated Article IV \& 2 (the Privileges and Immunities Clause). The claim was that an antisuit injunction denied citizens the privilege, which they otherwise would have, of bringing a cause of action in a foreign state. The Court disposed of this issue in a few cursory sentences, holding that, while the courts of another state might have been able to hear the cause of action, if they had not, "it would not follow that the courts of [the state issuing the antisuit injunction] violated any privilege or immunity of [that state's] own citizens in exercising their undoubted jurisdiction over them." Id at 113-14.

62 See id at 120-21. 
temic breakdown. ${ }^{63}$ For instance, one New York court wrote: "[I]f the courts of one State should see fit to enjoin proceedings in another, the latter might retaliate in like manner in enjoining proceedings in the first, and thus give rise to an endless conflict of jurisdiction.." ${ }^{\text {"st }}$ The Supreme Court avoided this argument by insisting that "the injunction is not directed to the courts of the other State, but simply to the parties litigant." The Court held that the power to control the "parties litigant" did not exceed the constitutional constraints on state courts' powers.

\section{B. Recognition}

The Supreme Court has not yet addressed the question of whether the Full Faith and Credit Clause requires state courts to recognize antisuit injunctions. ${ }^{67}$ Nevertheless, there are strong reasons, precedential and practical, to believe that the Court will find that antisuit injunctions are outside the ambit of the Full Faith and Credit Clause. Virtually every state court to consider the question has found that full faith and credit does not require it to recognize antisuit in-

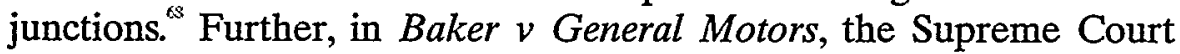
suggested, albeit in a footnote, that it will not extend the protection of the Full Faith and Credit Clause to antisuit injunctions.

63 See id.

64 Id, summarizing the argument made in Mead v Merritt, 2 Paige Ch 402 (NY Ch 1831).

65 Cole, 133 US at 134. Although the Supreme Court rejected this line of argument in Cole, it embraced it seventy-four years later in Donovan $v$ City of Dallas, 377 US 408 (1964). In Dono$v a n$, the Court held that a state court could not enjoin a litigant before it from proceeding with a cause of action in federal court. The Court made clear its displeasure with the argument that "the prohibition here was addressed to the parties rather than to the federal court itself," writing that:

[W] here the jurisdiction of a court, and the right of a plaintiff to prosecute his suit in it, have once attached, that right cannot be arrested or taken away by proceedings in another court.... The fact, therefore, that an injunction issues only to the parties before the court, and not to the court, is no evasion of the difficulties that are the necessary result of an attempt to exercise that power over a party who is a litigant in another and independent forum.

Id at 413 , quoting Peck $v$ Jenness, 48 US 612, 625 (1847). Note that the "evasion" dismissed by the Donovan Court is precisely the line of argument embraced by the Court in Cole. Scholars have also criticized the use of this distinction to uphold extraterritorial state injunctions. See Price, 84 Va L Rev at 841 (cited in note 8) (writing that traditional extraterritorial injunctions pose only comity concerns but that similar injunctions in an interstate/federal system threatens "the coexistence of the states as linked sovereignties").

66 Cole, 133 US at 134.

67 See Baker v General Motors Corp, 522 US 222, 236 n 9 (1998) (Ginsburg) (noting that the Court "has not yet ruled on the credit due to a state-court injunction barring a party from maintaining litigation in another State"), citing Ruth Bader Ginsburg, Judgments in Search of Full Faith and Credit: The Last-in-Time Rule for Conflicting Judgments, 82 Harv L Rev 798, 823 (1969).

68 For a discussion of the treatment of antisuit injunctions by state courts, see Part I.C.

69 See Baker, 522 US at $236 \mathrm{n} 9$ (expressing concern that the courts of one state not exer- 
State courts are typically reluctant to extend full faith and credit to judgments beyond cases in those categories found by the Supreme Court to require its application. Not surprisingly, they have been adamant and nearly universal in rejecting a reading of the Full Faith and Credit Clause that would require recognition of antisuit injunctions. ${ }^{70}$ This reluctance is understandable: If a state supreme court were to find that the Full Faith and Credit Clause requires the recognition of antisuit injunctions, the finding would force all courts in that state to unilaterally disarm themselves against the potential encroachments of courts in other states.

In Baker v General Motors Corp, ${ }^{n}$ the Supreme Court noted an exception in the traditional mandate of the Full Faith and Credit Clause, which requires that a judgment issued in one state be given the same preclusive effects in every other state that it would be given in the issuing state. ${ }^{72}$ The enforcement of judgments were subject to "the evenhanded control of forum law,", rather than the dictates of the

cise control over courts of other states). Most commentators have agreed. See, for example, Joan Steinman, Managing Punitive Damages: A Role for Mandatory "Limited Generosity" Classes and Anti-suit Injunctions?, 36 Wake Forest L Rev 1043, 1103-04 (2001); Susan F. Appleton, Surrogacy Arrangements and the Conflict of Laws, 1990 Wisc L Rev 399, 453-54 ("Most authorities concede [ ] that full-faith-and-credit principles do not require deference [to antisuit injunctions] even when issued by sister-state courts."); Willis L.M. Reese, Full Faith and Credit to Foreign Equity Decrees, 42 Iowa L Rev 183, 198 (1957) ("[T]here is something obnoxious in the thought that a court must accept as conclusive another's determination that suit before it would be unfair."). For a vigorous, if not persuasive, argument for application of the Full Faith and Credit Clause to antisuit injunctions, see Comment, Full Faith and Credit to Foreign Injunctions, $26 \mathrm{U}$ Chi L Rev 633, 642 (1956) (arguing that "since foreign injunctions cannot meaningfully be distinguished from other judgments, they cannot properly be made an exception to the normal command of full faith and credit").

70 See Robbins v Reliance Insurance Co, 2001 Tex App LEXIS 7367, *13 ("It would be contrary to Texas law and public policy for a Texas state court to stay a pending case pursuant to an anti-suit injunction ... unless the relevant Texas Insurance Code provisions ... have been complied with."); Mahan $v$ Gunther, 278 Ill App 3d 1108, 663 NE2d 1139, 1144 (1996) (holding that there is no constitutional compulsion to give full faith and credit to foreign antisuit injunctions). See also Spear v McDermott, 121 NM 609, 916 P2d 228, 240 (Ct App 1996) ("Neither the fullfaith-and-credit principle nor the concept of comity requires recognition of an attempt by one court to abate or stay proceedings in a different court."). But see Bard $v$ Charles R. Myers Insurance Agency, Inc, 839 SW2d 791, 795 (Tex 1992) (finding that an antisuit injunction was entitled to full faith and credit when it was embedded in a final order of an Indiana court).

71522 US 222, 231-36 (1998) (holding that full faith and credit does not apply to antisuit injunctions).

72 See Fauntleroy v Lum, 210 US 230, 237-38 (1908) (applying the Full Faith and Credit Clause to require that a Mississippi court give full faith and credit to a Missouri judgment even though the judgment reflected a "misapprehension" of Mississippi law). See also William L. Reynolds, The Iron Law of Full Faith and Credit, 53 Md L Rev 412, 412 (1994) (arguing that the Full Faith and Credit Clause imposes a "mandatory comity" on states that is "so clear and strong that it might be called the 'Iron Law' of Full Faith and Credit").

73 Baker, 522 US at 235. See also id at 241 (Scalia concurring) ("The Full Faith and Credit Clause did not make the judgments of other States domestic judgments to all intents and purposes, but only gave a general validity, faith, and credit to them, as evidence.") (quotation marks omitted). 
Full Faith and Credit Clause-but only under certain circumstances. For instance, forum law may control when enforcement mechanisms "interfere[] with litigation over which the ordering State had no authority." ${ }^{74}$ As an example of this type of order, the majority in Baker offered antisuit injunctions, approvingly adding in a footnote that "[s]tate courts that have dealt with the question have, in the main, regarded antisuit injunctions as outside the full faith and credit ambit." ${ }^{, 75}$

In addition to this suggestion, the Court signaled elsewhere in the case that it would not require courts to give full faith and credit to antisuit injunctions. Justice Ginsburg, writing for the majority, cited a law review article she had authored as a professor approving the nonrecognition of antisuit injunctions. ${ }^{76}$ Additionally, the Court supplied a policy rationale for not granting full faith and credit to antisuit injunctions, noting that to require recognition of these injunctions would allow "the courts of one state [to] control what goes on in the courts of another." ${ }^{n}$ Combined with the Court's description of antisuit injunctions as the type of extraterritorial order that "interferes with litigation," these statements strongly imply that the Court is not likely to find that the Full Faith and Credit Clause requires recognition of antisuit injunctions.

\section{A CRITICAL REVIEW OF THE STANDARDS FOR ISSUING ANTISUIT INJUNCTIONS}

This Part examines the justifications undergirding the two predominant standards for issuing antisuit injunctions ${ }^{78}$ and analyzes whether these justifications are sufficient to persuade a "recipient sovereign to acknowledge, accept and abide [their] issuance." I I conclude that when antisuit injunctions are issued on the strict standard, courts in sister states have strong reasons to recognize those injunctions, but that when antisuit injunctions are granted under the lax standard, courts in sister states have little reason to recognize them. Part IV will employ this finding as the foundation for establishing a new approach to recognition of antisuit injunctions.

74 Id at 235.

75 Id at $236 \mathrm{n} 9$.

76 See id ("The current state of the law, permitting [an antisuit] injunction to issue but not compelling any deference outside the rendering state, may be the most reasonable compromise between ... extreme alternatives."), quoting Ginsburg, 82 Harv L Rev at 823 (cited in note 67).

77 Baker, 522 US at $236 \mathrm{n}$ 9, quoting Reese, 42 Iowa L Rev at 198 (cited in note 69). The inclusion of this concern is interesting because the Court disregarded this concern when it considered the question of whether states could issue antisuit injunctions in Cole v Cunningham, 133 US 107 (1890). See Part II.A.

78 For an in-depth discussion of the effect and significance of each standard for issuance, see Part III.

79 Forum Insurance Co v Bristol-Myers Squibb Co, 929 SW2d 114, 117 (Tex App 1996). 
A. Antisuit Injunctions Should Be Recognized When Issued on a Strict Standard

Virtually all state courts will issue an injunction in three situations embraced by the strict standard, as laid out above: (1) when the jurisdiction of the court itself is threatened; (2) when it is necessary to protect an important public policy of the issuing state; and (3) when litigation in the alternative venue has been filed out of bad faith or for reasons of harassment. Whatever one might think of the merits of the first three reasons for issuing injunctions, the universality of their acceptance among state courts suggests that there is a practical need for courts to enjoin litigants in these situations. Thus, when a court issues an antisuit injunction in one of these three situations, the issuing court will have granted an injunction that all courts recognize as appropriate.

If a court does not recognize an antisuit injunction when it is granted under these circumstances, its reason for doing so cannot be that it does not think legitimate grounds existed for the issuing court to act as it did. Rather, its rationale must rest on either (1) a blanket refusal to recognize the judicial orders of a sister state unless required to do so by full faith and credit, or (2) an independent reweighing of the facts to find that the prerequisite situation for issuing the injunction did not actually exist. Neither rationale can be supported in a federal system of coordinate sovereigns.

For reasons of comity and reciprocity, a court should not deny effect to a sister court's order simply because it would have weighed the facts differently. A Texas appellate court recently wrote, "[c]omity, once invoked through anti-suit injunction, can only obtain its full potential and effect through the willingness of the recipient sovereign to acknowledge, accept and abide its issuance." This idea forms the basis of the legal principle of res judicata: Once an issue has been fully adjudicated, the issue may not be reopened in later litigation, regardless of whether the latter court might have reached a different conclusion. The foundations of this principle apply with equal force here. Where an antisuit injunction has been issued in one of the three situations embraced by the strict standard, it is inappropriate for a court in a sister state to reopen the issue and make an independent judgment. For functional reasons, as well, courts should respect the order of a sister state. A court's refusal to recognize another state's order today may lead that other state to refuse to recognize its order tomorrow.

80 These three situations represent the grounds for issuance under the strict standard. For a more detailed discussion of the strict standard, see Part I.B.1.

81 Forum Insurance Co v Bristol-Myers Squibb Co, 929 SW2d 114, 117 (Tex App 1996). 
A court's interest in reciprocity is especially acute where it employs the strict standard. As discussed in Part I.B.1, antisuit injunctions granted under this standard are intertwined with the protection of the interests of the forum. Thus, courts that employ the strict standard are not acting merely to manage litigation, but to protect their own interests: to stop litigants from avoiding an important public policy, to prevent other forums from usurping their jurisdiction, or to punish bad actors in the litigation process. The interests of courts that issue under the strict standard are thus clearly more significant than those of courts that issue under the lax standard.

\section{B. Antisuit Injunctions Should Not Be Recognized When Issued Under the Lax Standard}

Unlike the strict standard, issuance under the lax standard does not give rise to a rationale sufficiently compelling to persuade a "recipient sovereign to acknowledge, accept and abide its issuance." When issuing an injunction under the lax standard, a court has a lesser interest in the injunction domestically, and a lesser interest in having it abided abroad. First, the motivations behind the lax standard are different in kind from those discussed above. When a court issues an injunction in this situation, it makes its determination based on a consideration of the interests of the parties. Second, there is considerable disagreement among state courts as to whether it is appropriate to enjoin parties in order to avoid duplicative litigation. ${ }^{85}$ Thus, a court in this circumstance cannot rely on reciprocal treatment from courts in sister states because many of those states would not issue an antisuit injunction in the same circumstances.

A court's diminished interest under the lax standard becomes especially apparent when one considers that the litigants' interests may be protected by other means. If the issuing court's aim is to avoid duplicative litigation, it could easily stay the litigation and allow the proceedings in the other state to go forward, achieving the same result of alleviating the burden on the litigants. ${ }^{34}$ Thus, even if the issuing court decides that litigation should only proceed in one forum to protect against the time and expense of duplicative litigation, there is no reason for a court to acquiesce to its attempt to gain exclusive jurisdiction

82 Id at 117.

83 For a discussion of the practical significance of this difference in standards, see Part I.B.

84 This practice of deference to courts in sister states is common in parallel litigation. For instance, under the "first-to-file" rule, the court where the cause of action was most recently filed is expected to stay the action, pending resolution in the forum where the cause of action was first filed. See, for example, St. Paul Surplus Lines Insurance Co v Mentor Corp, 503 NW2d 511, 514 15 (Minn Ct App 1993) (stating that where two courts have jurisdiction, the first court to acquire jurisdiction has priority over the matter). 
by recognizing its antisuit injunction. When not issued for reasons related to systemic viability, such an injunction becomes nothing more than an aggressive attempt to seize exclusive jurisdiction.

Weighed against the diminished interest of the forum and the pressure of viable alternatives, the benefits of antisuit injunctions issued under the lax standard do not overcome the considerable systemic costs. ${ }^{85}$ When a court issues an antisuit injunction, courts in other states face the unappetizing choice between (a) abiding the willful act of a foreign court and (b) retaliating by ignoring the other court's order or issuing an antisuit injunction of their own. Before a court creates this conflict, it should, in the first instance, be certain that the action it takes is justified by a corresponding benefit. This level of benefit may be present when the injunction is issued to protect the forum's own interests. But when the injunction is issued primarily to protect litigants - as it is under the lax standard, the same cannot be said. Antisuit injunctions should not be granted simply to avoid a multiplicity of litigation.

\section{A PROPOSAL FOR RECOGNITION OF ANTISUIT INJUNCTIONS}

This Part will discuss ways in which a court faced with antisuit injunctions may respond. It will first argue that, because antisuit injunctions are more appropriate in some circumstances than in others, courts should not treat all antisuit injunctions in the same manner. The remainder of the Part examines different approaches to differentiating between injunctions. It argues that, in evaluating antisuit injunctions, a rules-based approach is preferable to a regime that would require a court to evaluate the merits of each injunction. The Part then confronts the possibility that a rules-based approach will be open to manipulation. With this difficulty in mind, it suggests that one approach to the recognition question is preferable to others.

\section{A. Promoting Comity by Limiting Recognition}

All antisuit injunctions are not created equally. In different states, they may never be issued, issued only in rare circumstances, or issued whenever there is a danger of duplicative litigation. The decision of courts in sister states about whether to recognize these injunctions should depend on the standards upon which they were originally granted.

The primary obstacle to the adoption of a proposal that seeks to promote comity between courts is that it requires some states to act as "first movers" - to adopt a policy of unilateral disarmament without 
any guarantee of reciprocation from other states. ${ }^{86}$ This concern is equally relevant to the consideration of whether to adopt the proposal developed in Part III, that states use a strict standard for issuing antisuit injunctions. States that choose this option will be at a strategic disadvantage relative to states that continue to issue injunctions under the lax standard because the latter will be able to restrain litigants in a greater number of cases. To overcome similar collective action problems, some commentators in the conflicts field propose that Congress pass national legislation. This solution may even be available with regard to the recognition of antisuit injunctions. ${ }^{\$ 8}$ Nevertheless, it is highly unlikely that Congress will engage in such a project and, if it did so, there is no consensus as to the shape that its solution should take. Moreover, there are a number of reasons why a uniform approach to the recognition of antisuit injunctions might not be desirable."

To neutralize first-mover disadvantages, this Comment suggests that states implement an approach that focuses on the recognition of antisuit injunctions and is based on the concept of reciprocity. Because the impact of any antisuit injunction occurs outside of the issuing state, such injunctions are only as effective as other states' willingness to abide them. A state interested in promoting comity may neutralize bad actors by refusing to recognize injunctions issued under the lax standard. In so doing, these courts would gain the ability to impose a penalty on uncooperative behavior, while retaining a regime that respects and abides the actions of courts in other states.

86 For a general discussion of this difficulty, see Larry Kramer, Rethinking Choice of Law, 90 Colum L Rev 277, 340 (1990) (writing that without reciprocity, "any gains in multistate policies and reduced forum shopping are likely to be too small to compensate for the sacrifice of State A's domestic policies").

87 See Ralph U. Whitten, Commentary, Curing the Deficiencies of the Conflicts Revolution: A Proposal for National Legislation on Choice of Law, Jurisdiction, and Judgments, 37 Willamette L Rev 259, 262 (2001) (suggesting an incremental approach for the formulation of national conflicts of laws legislation).

88 See id at 292 (" $[N]$ o constitutional obstacle exists to prevent Congress from enacting a statute requiring that the states give effect to non-final judicial proceedings in other states."). As non-final judicial proceedings, antisuit injunctions fall into this category.

89 Likewise, resolution of the problem through appeal to the American Law Institute (ALI) is not likely to prove successful. There simply does not exist the appetite or the consensus necessary to compile another Restatement on Conflict of Laws. And, even if there were, it is not clear that the proposed solution of a new Restatement would persuade courts to follow its lead. The adoption of the last attempt of the Restatement (Second) of Conflict of Laws (1971) has been uneven and far from universal. See generally Symeon C. Symeonides, The Judicial Acceptance of the Second Conflicts Restatement: A Mixed Blessing, 56 Md L Rev 1248, 1261-69 (1997) (examining the level of acceptance of the Restatement (Second) among state courts). 


\section{B. Different Approaches to Recognition}

In order for this proposal to be viable, states must be able to tell the difference between those states that adopt a pro-comity approach and those that do not. Towards this end, this section evaluates three proposals for differentiating between antisuit injunctions. ${ }^{90}$

First, the court could evaluate the legitimacy of the injunction de novo, on a case-by-case basis. It would recognize the injunction if it feels that the injunction was warranted, or else dispense with it. Second, a court could evaluate only the standard under which the injunction was awarded. If the injunction was awarded based on the strict standard, then the court would recognize it. If the injunction was awarded on the basis of the lax standard, then the court would ignore it. Third, a court could evaluate the injunction based on the standard of the issuing state. If the state allows issuance of antisuit injunctions on the lax standard, then the court, as a rule, would ignore the injunction regardless of whether the actual issuance fits within the strict standard. If the state issued injunctions only on the strict standard, the court would recognize the injunction.

The adoption of any of these proposals would have benefits and drawbacks. At this point, it is important to note that each represents a viable approach to the recognition of antisuit injunctions." This can be seen in the existence of analogs to each approach in other areas of law. $^{\text {s2 }}$

90 There are, of course, other ways by which a court might address antisuit injunctions issued by other states. These include both universal recognition and non-recognition. As discussed in Part II of this Comment, neither solution is desirable. It should be noted, however, that nonrecognition is similar to the first solution addressed in this Part. The primary difference is that, in the first approach, the court evaluates the legitimacy of the injunction, not the legitimacy of the litigation going forward. Although these two inquiries will likely produce the same result, they represent different inquiries.

91 There might be some concern that courts will have difficulty determining what standards other states use for issuing antisuit injunctions. Such a concern would be misplaced. Courts are commonly asked to apply the law of other states in the choice of law context. Traditionally, courts rely on litigants to supply the foreign state's law, but modern courts have undertaken the task of determining the law for themselves. See David P. Currie, Herma Hill Kay, and Larry Kramer, eds, Conflict of Laws: Cases, Comments, Questions 85-88 (West 6th ed 2001).

92 The viability of the first approach embodies the approach that states currently use to evaluate antisuit injunctions. An analogue to the second proposal can be found in the system used to determine whether judgments merit full faith and credit. Prior to deciding to recognize a judgment from another jurisdiction, a state must first determine (1) whether the court to issue the judgment had jurisdiction over the parties, and (2) if it is an equitable judgment, whether the equitable relief unduly interferes with litigation in its own jurisdiction. See Baker, 522 US at 232, 235-36. In this process, as in the second approach, the court is required to look into the justification given by the issuing court to determine whether or not to recognize the injunction.

The analogue to the third approach can be found in Nebraska's choice of law rules with regard to small loan contracts. Nebraska recognized contracts made in states where the law differed from Nebraska's so long as that law was "similar in principle." As in the third approach, Nebraska's recognition of these contracts was based upon an understanding that the law of the 
1. Recognition based on a de novo review of the injunction, performed on a case-by-case basis.

This is the regime currently followed by most states. ${ }^{93}$ As described in Part I.C of this Comment, comity-if invoked at all-plays the role of tiebreaker, a proxy for an independent decision of a court that the cause of action should not proceed in its forum. Because recognition is a matter of discretion, courts rarely feel compelled to defer to another court when they believe that it is a more appropriate forum for the litigation."

Nevertheless, as this Comment has demonstrated, this regime is costly in terms of reduced comity between courts and confusion among litigants. It is also problematic because it offers no incentive for courts to adopt a higher standard for issuing antisuit injunctions. The decision to recognize an antisuit injunction depends wholly on the desire of the reviewing court to entertain the cause of action. The considerations given for the issuance of the injunction are irrelevant. Moreover, there is still a potential benefit from issuing an antisuit injunction. Even if the injunction is not recognized outside of the forum state, it may serve to give the issuing court exclusive jurisdiction. After all, the enjoined litigants continue to be subject to the court's contempt powers. Thus, it is rational for an issuing court to grant an antisuit injunction whenever it would like to assert exclusive jurisdiction.

\section{Recognition based on a case-by-case review of the standard of issuance.}

This proposal would require a court to evaluate the reasons given for the issuance of each injunction it was being asked to recognize. If the injunction was issued in a state that only granted injunctions based on the higher standard, then the court would recognize the injunction without looking any further. If the injunction was issued in a state that used the lax standard, the court would evaluate the particular grounds on which the injunction was granted. If the injunction were granted to avoid a multiplicity of litigation, the reviewing court would not recognize the injunction and allow the cause of action to proceed. Courts only recognize antisuit injunctions when they are issued for one of the three reasons that constitute the strict standard.

sister state was based upon a common principle. See Brainerd Currie, Notes on Methods and $O b$ jectives in the Conflict of Laws, in Selected Essays on the Conflict of Laws, 177, 186-87 (Duke 1963) (asserting that there is room for "restraint and enlightenment" when a state is determining its policies and interests).

93 For a discussion of the treatment of antisuit injunctions by states, see Part I.C.

94 See notes $49-50$ and accompanying text. 
This approach is superior to the first approach because it provides issuing courts an incentive to take account of the interests of sister-state courts. As with any rule-based approach, this approach is subject to manipulation by courts. This potential difficulty will be discussed in more detail below.

3. Recognition based on systemic evaluation of the standard of issuance.

This final approach recommends that whenever a foreign jurisdiction employs the lax standard for issuing antisuit injunctions, a reviewing court should respond by not recognizing that injunction, regardless of whether that party could have obtained an injunction under the strict standard. However, when the issuing court employs the strict standard, courts in other states should recognize and enforce the injunction, again without reference to whether an injunction should have been issued in this particular instance. As with the constitutional requirement that final judgments receive full faith and credit in sister states, courts deciding whether to recognize antisuit injunctions would not be allowed to re-evaluate the reasoning employed by the issuing court; the only issue would be whether the issuing court's state employed the strict standard. Past that, the reviewing court would recognize the injunction and stay the cause of action.

The adoption of this approach is likely to have greater systemic impact than the first two approaches, by encouraging other states to adopt the strict standard. However, until the strict standard gains widespread acceptance, this approach would also produce satisfactory results in fewer cases. In many cases, a court following this approach would not recognize an injunction even when it believed it to be appropriately issued because the injunction was granted in a state that uses the lax standard.

\section{The Benefits of a Rule-Based Approach}

The second and third approaches, if adopted, would both improve upon the current approach to antisuit injunctions. Professor Larry Kramer has suggested that new choice of law rules be judged on three criteria: (1) the advancement of multistate policies, (2) the reduction of forum shopping, and (3) a greater assurance that each state's law is applied in the cases the state cares about most. ${ }^{\text {sh }}$ Both the second and the third approaches satisfy Kramer's criteria.

96 See Kramer, 90 Colum L Rev at 319 (cited in note 86). 
The first prong is easily satisfied. Either approach would advance multistate policies by increasing the predictability of court decisions. The adoption of a rules-based approach would provide a court considering the issuance of an antisuit injunction with guidance about how that injunction will be received in sister states. More directly, both approaches would relieve litigants of the difficult situation of having to proceed in the face of conflicting orders in state courts-so long as the injunction is not issued on the lax standard. Increased predictability as well as greater comity between courts is in the long-term interest of both courts and litigants.

Second, the rules-based approaches would reduce forumshopping by promoting uniformity amongst the state courts. To the extent that a rules-based approach discourages courts from granting antisuit injunctions on a lax standard, either the second or the third approach would make it more difficult to avoid the jurisdiction of a foreign venue by obtaining an antisuit injunction. That said, any effect on forum shopping will be minimal. There are myriad reasons to forum shop; ${ }^{97}$ the willingness of a jurisdiction to issue antisuit injunctions will seldom prove dispositive in most litigants' choice of forum.

Finally, and most importantly, the second and third approaches allow states to apply their own law in the cases that they care about most. As discussed, both approaches allow and require recognition of issuance of antisuit injunctions under the strict standard-just those instances when the state's interests are most at stake. Thus, a state could choose the second or third approach to the recognition of antisuit injunctions without reducing its ability to protect its own legitimate interests.

\section{Objections to a Rules-Based Approach}

An objection to the rules-based approaches may be that, to the extent that they describe at the outset the type of antisuit injunctions that will and will not be recognized, they are susceptible to manipulation by issuing courts. For instance, a court that wants to grant an injunction under the lax standard might also include some of the rationales in the stricter standard in order to secure recognition in foreign courts. If one believes that judges will issue disingenuous orders so as to promote the power of their jurisdiction, this criticism has some force.

97 See generally Mary Garvey Algero, In Defense of Forum Shopping: A Realistic Look at Selecting a Venue, $78 \mathrm{Neb} \mathrm{L}$ Rev 79 (1999) (describing the many motivations that might lead a litigant to forum shop).

98 Given the courts' willingness to manipulate the standards of the First and Second Restatement, this possibility should not be discounted here. For a humorous description (and notorious example) of judicial machinations in this area, see Judge Richard Neely's account in Paul $v$ 
However, two considerations lessen the force of this criticism. First, judges do not act with impunity: Their decisions are subject to appellate review, and the threat of reversal provides an incentive against the manipulation of the law. Second, even if a judge is willing to manipulate his orders, a rules-based regime would still pose greater obstacles to his aims than a discretion-based approach. As Professor Kramer writes, "It is difficult to see how abandoning [rules-based approaches]-thereby making it easier for judges to rely surreptitiously on unstated, idiosyncratic background assumptions-makes for better decisionmaking." ${ }^{.9}$ A judge who seeks to use an injunction for reasons not recognized by the second or third approaches will, at least, have to reveal his surreptitious reasoning in a published opinion; this opportunity for exposure will make manipulation less enticing.

\section{E. The Superior Rule}

Among the rules-based approaches, the third approach is superior to the second for three reasons. First, it presents a significantly larger obstacle to manipulation. Second, it provides incentives for states to switch to more systemic use of the strict standard. Lastly, it is easier for courts to apply.

A clever court could manipulate the rule set forth by the second approach. For instance, imagine that a court wants to grant an injunction to avoid duplicative litigation. Yet, if granted for this reason, sister-state courts would not recognize it. The court, understanding this, may grant the injunction anyway, surreptitiously basing its order on a rationale recognized under the strict standard. Thus, its injunction would receive recognition under the second approach, even though the genuine reason for its issuance would not have qualified it for recognition.

The third approach avoids this difficulty by narrowing the category of courts that could succeed with manipulation. It categorically denies recognition to antisuit jurisdictions when the injunction was issued by a regime that used the lax standard. This leaves open the possibility that a court that uses the strict standard for issuance might still disingenuously issue an antisuit injunction even though, under its own law, the injunction did not qualify for issuance under any legal standard. But it seems unlikely that this level of manipulation will occur with enough frequency to undermine the benefits of the third ap-

\footnotetext{
National Life, 177 W Va 427, 352 SE2d 550, 556 (1986) (writing that "if we are going to manipulate conflicts doctrine in order to achieve substantive results, we might as well manipulate something we understand," and holding that the First Restatement's clear rule did not apply due to an exception for West Virginia's important public policy).

99 Kramer, 90 Colum L Rev at 320 (cited in note 86 ).
} 
proach. Appellate review should pose a sufficiently significant threat to deter all but the most devious courts from issuing an antisuit injunction disingenuously.

Finally, the third approach is superior to the second because it creates strong incentives for other states, not just other courts, to switch to the strict standard for issuance. By only recognizing injunctions from states that use the strict standard-and refusing to recognize antisuit injunctions issued under a lax standard-the third approach unambiguously favors those states that use the strict standard. Common law rules, as established norms, are notoriously difficult to change. The use of a strong rule may be necessary to send a signal of sufficient clarity and force to trigger a switch to a strict regime."

The strongest objection to the third approach may be that it requires courts to ignore antisuit injunctions issued in states that recognize the lax standard, when it would compel recognition of the injunction if it had been issued in a strict standard state under the same circumstances. There are three reasons not to be overly concerned about this result. First, the denial of recognition only seems unjust in relation to the reciprocity-based approach afforded to antisuit injunctions proposed in this Comment. When compared to the approach followed by states currently, the beneficiary of an antisuit injunction is no worse off; the injunction would not be recognized in a sister-state under either regime. Second, due to concerns about manipulation (discussed above), there are reasons to be wary of any injunction issued by a regime that operates under the lax standard. ${ }^{101}$ If other states were to adopt an approach that recognized injunctions issued under certain conditions, lax-standard courts would have an even greater incentive to disguise their reasons for issuance. Finally, the motivation for departing from the current regime of non-recognition is driven by a desire to avoid systemic breakdowns, where courts in coordinate states compete with one another to obtain jurisdiction over certain litigation. The denial of the benefit of an antisuit injunction to certain, unlucky litigants must be weighed against these concerns.

100 See Randal Picker, Simple Games in a Complex World: A Generative Approach to the Adoption of Narms, 64 U Chi L Rev 1225, 1283-85 (1997). As Professor Picker notes, the demonstration that a proposed solution is a "cooperative" equilibrium position does not mean that the behavior of players in the game will necessarily evolve towards that equilibrium. The difficulty is shifting practices from one equilibrium to another. See id at 1283 (suggesting that one way to shift norms is to seed small communities of actors with a strong preference for the new norm).

101 Discussed in detail in Part III.B. 


\section{CONCLUSION}

This Comment aims to develop a rule that avoids conflict between courts when parallel lawsuits have been filed. Specifically, it seeks to fend off the systemic breakdown that occurs when courts compete with one another for exclusive jurisdiction. In this event, a litigant is forced to choose between (a) abiding by the injunction of one court, risking the entrance of a default judgment against him in another, and (b) proceeding in the face of the injunction, raising the possibility that he will be held in contempt by the issuing court.

By stating explicitly the difficulties with antisuit injunctions in parallel litigation, this Comment seeks to provide a framework by which commentators and courts may develop a more systemic answer to the problems they pose. Ultimately, the Comment urges the adoption of a strong rule, based on reciprocity between co-equal sovereigns, by which courts could formalize the relationship between issuance and recognition.

Modern conflict of laws scholarship suggests that the process of formalization and the development of rules increases the likelihood that surrounding states will alter their behavior to reflect that of the adopting state. ${ }^{102}$ Following the lead of these commentators, this Comment argues in favor of the establishment of more predictable standards by which courts could consider whether to issue and recognize antisuit injunctions. In so doing, it attempts to promote comity between state courts by formalizing a viable system of reciprocity.

\footnotetext{
102 See Lea Brilmayer, Conflict of Laws 155-69, 180-81 (Little, Brown 1991) (explaining the benefits and disadvantages of a system of specific reciprocity); Larry Kramer, 90 Colum L Rev at 339-44 (cited in note 86) (using game theory to argue that courts in sister states will evolve to embrace cooperative approaches).
} 